The development of homozygous maize lines using an in vivo haploid induction in the Croatian germplasm

Razvoj homozigotnih linija kukuruza pomoću indukcije haploida in vivo u hrvatskoj germplazmi

Mazur, M., Vila, S., Brkić, I., Jambrović, A., Šimić, D.

Poljoprivreda/Agriculture

ISSN: 1848-8080 (Online)

ISSN: 1330-7142 (Print)

http://dx.doi.org/10.18047/poljo.25.1.3

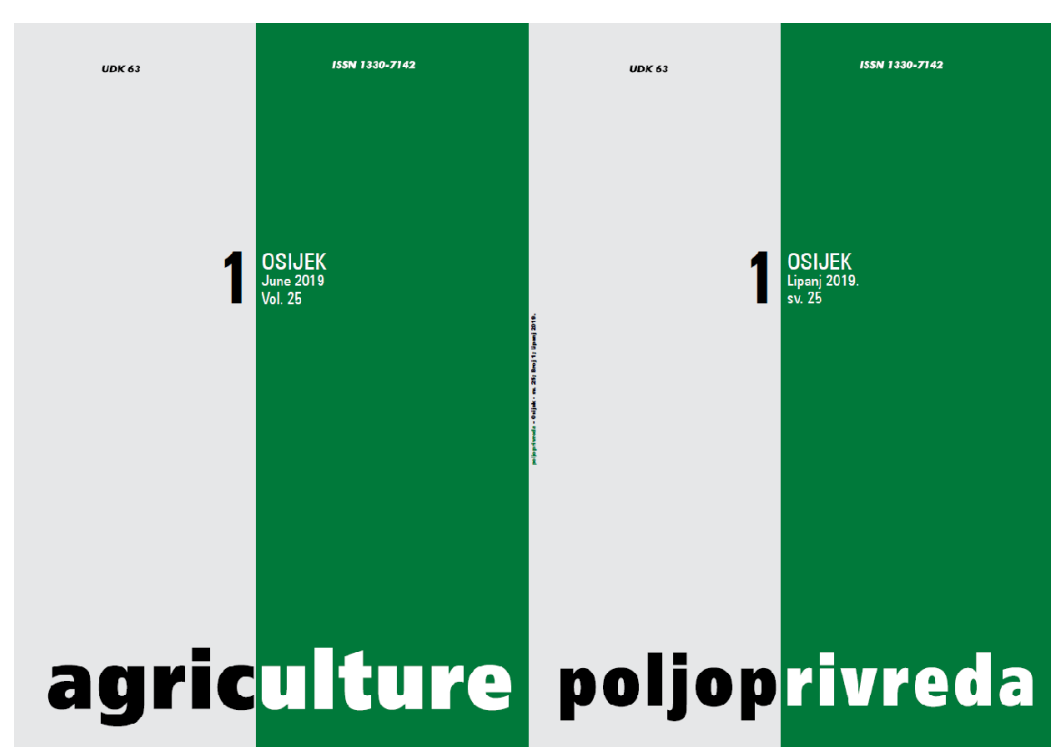

Fakultet agrobiotehničkih znanosti Osijek, Poljoprivredni institut Osijek

Faculty of Agrobiotechnical Sciences Osijek, Agricultural Institute Osijek 


\title{
THE DEVELOPMENT OF HOMOZYGOUS MAIZE LINES USING AN IN VIVO HAPLOID INDUCTION IN THE CROATIAN GERMPLASM
}

Mazur, M. (1), Vila, S. ${ }^{(2)}$, Brkić, I. ${ }^{(1)}$ Jambrović, A. ${ }^{(1,3)}$, Šimić, D. ${ }^{(1,3)}$

\begin{abstract}
SUMMARY
The in vivo haploid induction has been widely applied to the maize breeding in recent decades, but it has not been used in the breeding programs in the Republic of Croatia by now. This study's objectives were to examine the haploid induction rates in the Croatian germplasm and to evaluate the properties of the DO haploids, which are essential for a successful implementation of this method in breeding. The in vivo haploid induction was performed on 11 single-cross hybrids using the Zarodyshevy Marker Krasnodarsky (ZMK) inducer, and colchicine was used as a chromosome doubling agent. Emergence, misclassification rate, colchicine treatment survival, chromosome doubling rate and self-pollination success were examined in the DO generation. The haploid induction rates ranged from 6.9 to $15.8 \%$, which is consistent with the average induction rates characteristic of the ZMK inducer and the other modern ones. Significant differences were found among the populations of DO haploids for all tested properties, except for self-pollination success. On average, the misclassification rates were lower, and the seedling survival rates were higher than those reported in other studies, indicating a possibility of a successful application of the doubled haploid method in maize breeding.
\end{abstract}

Key words: in vivo haploid induction, doubled haploid lines, R-nj marker system, chromosome doubling, colchicine

\section{INTRODUCTION}

Maize (Zea mays L.) is a very important crop in economic terms, and great attention is paid to its breeding with a focus on high yield and grain quality (Galić et al., 2017). The selection of a source germplasm and breeding methods, together with a careful estimate of a breeder, are very important for the development of maize lines and hybrids. Although the concept of the usage of hybrids in maize breeding is still considered to be one of the greatest achievements in plant breeding, many changes in breeding methods, available tools, and information, as well as in the use of germplasm, have occurred. Traditional methods for inbred lines development require six to ten generations of self-pollination to obtain sufficient homozygosity (Hallauer et al., 2010). The in vivo haploid induction approach in maize is a newer method for the obtainment of homozygous lines. Because of several advantages compared to the traditional methods of line development, it has been widely applied to the maize breeding and genetics in recent decades, but it has not been used in the breeding programs in the Republic of Croatia by now. The main advantage of the doubled haploid method is an ability to obtain completely homozygous maize lines in only two seasons. Other advantages include a more rapid integra-

(1) Maja Mazur, Ph.D. (maja.mazur@poljinos.hr), Ivan Brkić, Ph.D., Antun Jambrović, Ph.D., Assoc. Prof. Domagoj Simić, Ph.D. - Agricultural Institute Osijek, Department of Maize Breeding and Genetics, Južno predgrađe 17, Osijek, Croatia, (2) Prof. Sonja Vila, Ph.D. - Josip Juraj Strossmayer University of Osijek, Faculty of Agrobiotechnical Sciences Osijek, Vladimira Preloga 1, Osijek, Croatia, (3) Antun Jambrović, Ph.D., Assoc. Prof. Domagoj Simić, Ph.D. - Centre of Excellence for Biodiversity and Molecular Plant Breeding, Svetošimunska 25, Zagreb, Croatia 
tion of the interest loci and increased usefulness over traditional lines developed (De La Fuente, 2015).

Since the success of the doubled haploid method depends on a number of factors, of which the choice of a donor material has a great impact (Smith et al., 2008; Bernardo, 2009; Wilde et al., 2010), it is necessary to examine the suitability of germplasm used in the domestic breeding programs for the application of this method. Thus, this study's objectives were to assess a haploid inducing ability of the Croatian germplasm, to evaluate the haploid induction rate, and to evaluate the properties of the DO haploids, which are essential for a successful implementation of the doubled haploid method in breeding.

\section{MATERIAL AND METHODS}

Eleven single-cross maize hybrids (denoted as genotypes) were chosen as a donor material for an in vivo haploid induction (Table 1). They contained the parental inbred lines developed at the Agricultural Institute Osijek. The hybrids were crossed to the ZMK inducer, which is homozygous on the $R-n j$ (R-Navajo) allele of the $\mathrm{R}$ locus, a dominant anthocyanin color marker expressed in the aleurone of the endosperm and in the scutellum of the embryo (Nanda and Chase, 1966). R-nj, as a dominant color marker, enables a screening of haploids in the kernel stage (Zhang et al., 2008). The ZMK inducer is characterized by an average induction rate of $6-8 \%$ (Shatskaya, 2010).

Table 1. Parental lines and maturity (FAO) group of eleven maize hybrids.

Tablica 1. Roditeljske linije i dužina vegetacije hibrida kukuruza.

\begin{tabular}{|l|l|c|}
\hline $\begin{array}{l}\text { Genotype } \\
\text { Genotip }\end{array}$ & \multicolumn{1}{|c|}{$\begin{array}{c}\text { Parental lines } \\
\text { Roditeljske linije }\end{array}$} & \multicolumn{1}{c|}{$\begin{array}{c}\text { FA0 group } \\
\text { Fao skupina }\end{array}$} \\
\hline OS 298P & 2748 C0/0s 2-48 & 280 \\
\hline OS 378 & Os 2340-8/0s 27488 & 360 \\
\hline DRAVA 404 & Os 942/0s 84-28 A & 420 \\
\hline OS 430 & Os 946/0s 84-28 A & 430 \\
\hline OSSK 444 & Os 135-88/0s 3-48 & 420 \\
\hline OSSK 515 & Os 84-28 A/0s 990 & 520 \\
\hline OS 499 & Os 87-24/0s 5-23 & 520 \\
\hline OSSK 552 & 0s 84-44/0s 1-44 & 550 \\
\hline OSSK 5717 & Os 84-28 A/0s 2695 C0 & 550 \\
\hline OSSK 596 & 0s 438-95/0s 1-44 & 600 \\
\hline OSSK 617 & Os 438-95/0s 6-2 & 610 \\
\hline
\end{tabular}

A haploid kernel selection was made with regard to the mature and dry kernels by a visual inspection of $R-n j$ color marker. The kernels with no expression of anthocyanin coloration in the scutellum but with a typical crown coloration on the endosperm are the putative haploids. The kernels with an expression of anthocyanin in both the endosperm and the scutellum are the diploids, and colorless kernels, if present, are a result of either selfing or contamination due to outcrossing. A frequency of the putative haploids was calculated as a percentage of haploid kernels in relation to all the kernels with an expressed color marker per ear and on average for each hybrid.

Putative haploids were sown in the field to form a D0 generation. In the DO generation, a visual inspection of the true haploid plants was performed prior to a chromosome doubling treatment with colchicine. The haploid plants were treated by a 0.125 -percent colchicine solution with $3 \%$ of dimethyl sulfoxide and $0.7 \%$ of methyl cellulose in the phases 3-5 of the developed leaves (Zabirova and Shatskaya, 1999). One week subsequent to the colchicine treatment, the haploid plants that survived the treatment were counted. The fertile DO haploid plants were self-pollinated to derive the doubled haploid (DH) lines, and the ears with a seed set were harvested manually subsequent to their physiological maturity.

The emergence of haploid plants, misclassification rates, colchicine treatment survival, chromosome doubling rates and self-pollination success were examined in the DO generation. Emergence was determined as a percentage of the number of seedlings in relation to the total number of seeds sown per plot, corrected for the misclassified putative haploids. Misclassification rates were calculated as a ratio of the false positives (hybrids) and the total number of seedlings per plot. A recovery success subsequent to a colchicine treatment was obtained as a ratio of the number of surviving haploid plants and a total number of true haploids per plot. The chromosome doubling rates were calculated as a percentage of haploids that displayed both a male and a female fertility versus a total number of plants surviving the colchicine treatment, while a self pollination success was calculated as a ratio between the number of 
haploids that formed at least one seed and the number of fertile haploids.

The coefficient of variation was calculated for the putative haploid induction rates as a relative indicator of variability. The $x^{2}$ test $(p<0.05$ and $p<0.01)$ was used to examine a significance of differences among the individual ears of each genotype for the induction rates and among populations for the examined properties in the DO generation.

\section{RESULTS AND DISCUSSION}

A frequency of putative haploids obtained subsequent to an in vivo haploid induction ranged from $6.9 \%$ to $15.8 \%$ (Table 2). This frequency is consistent with the average induction rates characteristic of the ZMK inducer, ranging between 6 and 13\% (Shatskaya, 2010), and other modern inducers (Röber et al., 2005; Zhang et al., 2008; Rotarenco et al., 2010; Prigge et al., 2011). Probably, the differences in the haploid induction rates among the examined genotypes are partially caused by genetic differences but also to the nongenetic factors, of which the temperature during selfing could have exerted the greatest impact. The genotype dependency of an in vivo system is much lower than the maize-related in vitro haploid systems (Geiger, 2009), and the haploid induction rates primarily depend on the potential of a haploid inducer (Lashermes and Beckert, 1988; Sarkar et al., 1994; Shatskaya et al., 1994; Chalyk, 1999; Röber et al., 2005; Kebede et al., 2011). Nevertheless, any given maternal haploid inducer will produce a range of induction rates in a large number of diverse germplasm (Eder and Chalyk, 2002; De La Fuente et al., 2018). Such occurrence indicates a quantitative control on the donor side due to several factors (Röber et al., 2005; Kebede et al., 2011; Prigge et al., 2011). Furthermore, the influence of other factors, such as the environment and temperature during the induction crosses (Kebede et al., 2011), an interaction between a location and a year (Röber et al., 2005), and a biotic and abiotic stress (Geiger, 2009), is not negligible. Higher putative haploid rates were mainly observed in the earlier genotypes (FAO 280-420), with the exception of OSSK 515 (FAO 520) (Tables 1 and 2). We assume that this performance might be a result of a genotype-specific inducibility, but it might be also partially caused by the very high temperatures during the pollination of later genotypes. This may be surmounted by a selection of an inducer that tolerates the dry and high temperature conditions which is essential for adaptation to the expected changes in the precipitation regime, as well as more frequent and intense temperature extremes (Jug et al., 2018). In addition, an earlier sowing of the later source genotypes should be considered. An alternative approach, proposed by De La Fuente et al. (2018), is to use a germplasm with an improved inducibility for breeding to improve the rates of inducibility in a germplasm that has the low induction rates.

Table 2. Putative haploid induction rates of eleven single-cross hybrids.

Tablica 2. Frekvencija navodnih haploida kod jedanaest jednostrukih hibrida kukuruza.

\begin{tabular}{|c|c|c|c|c|c|}
\hline \multirow{2}{*}{$\begin{array}{l}\text { Genotype } \\
\text { Genotip }\end{array}$} & \multicolumn{3}{|c|}{$\begin{array}{l}\text { Putative haploids } \\
\text { Navodni haploidi }\end{array}$} & \multirow{2}{*}{$\begin{array}{c}\text { Coefficient of variation (\%) } \\
\text { Koeficijent varijacije (\%) }\end{array}$} & \multirow{2}{*}{$\begin{array}{l}\chi^{2} \text { test } \\
\chi^{2} \text { test }\end{array}$} \\
\hline & $\begin{array}{l}\text { Number } \\
\text { Broj }\end{array}$ & $\begin{array}{l}\text { Average } \pm \text { SE }(\%) \\
\text { Prosjek } \pm \text { SE (\%) }\end{array}$ & $\begin{array}{c}\text { Range (\%) } \\
\text { Raspon (\%) }\end{array}$ & & \\
\hline OS 298P & 765 & $15.8 \pm 0.7$ & $9.8-22.7$ & 20.9 & n.s. \\
\hline OS 378 & 700 & $11.7 \pm 0.7$ & 3.3-20.3 & 33.5 & $* *$ \\
\hline DRAVA 404 & 1253 & $14.6 \pm 0.6$ & $6.0-22.7$ & 25.2 & $*$ \\
\hline OS 430 & 710 & $11.6 \pm 0.7$ & $0.0-21.6$ & 40.4 & $* *$ \\
\hline OSSK 444 & 557 & $10.7 \pm 0.6$ & $2.5-19.3$ & 34.0 & $* *$ \\
\hline OSSK 515 & 730 & $12.9 \pm 0.6$ & 5.9-22.6 & 28.3 & n.s. \\
\hline OS 499 & 492 & $8.3 \pm 0.6$ & 2.3-18.5 & 42.7 & $* *$ \\
\hline OSSK 552 & 382 & $6.9 \pm 0.5$ & $0.0-14.5$ & 44.5 & $* *$ \\
\hline OSSK 5717 & 655 & $10.2 \pm 0.6$ & $0.0-20.4$ & 37.6 & $* *$ \\
\hline OSSK 596 & 407 & $8.0 \pm 0.7$ & $0.0-14.0$ & 45.2 & n.s. \\
\hline OSSK 617 & 526 & $9.0 \pm 0.5$ & $4.4-15.7$ & 28.3 & n.s. \\
\hline
\end{tabular}

** - significant at $p<0.01$ / statistički značajno na razini $p<0,01$; ${ }^{*}$ - significant at $p<0.05$ / statistički značajno na razini $p<0,05 ;$ n.s. - not significant / nije značajno; SE - standard error / standardna pogreška

A haploid frequency also varied within each genotype, and significant differences were found between the individual ears in the seven examined genotypes (Table 2). Considering that the donor genotypes are genotypically uniform, we assume that these differen- ces were manifested due to the nongenetic influences, such as the weather conditions during pollination, but they could have been also caused by a variability within the inducer itself, knowing that ZMK inducer is not a homozygous line (Shatskaya, 2010). 
Significant differences at $p<0.01$ were found among the populations of the DO haploids for all the tested properties, except for a self-pollination success in the fertile D0 plants (Table 3). The emergence rates were quite low and ranged from 26.4 to $65.6 \%$, which had a significant impact on the final number of $\mathrm{DH}$ lines. The haploid plants are more sensitive to the weather conditions in the field and have higher demands for the soil tillering and care treatments than the diploid ones. The weather conditions subsequent to the sowing caused the emergence of a strong crust on the soil surface, having resulted in the low emergence rates and an uneven emergence, which considerably hampered the colchicine treatment of haploids in the optimal growth stage. Since each haploid seed, or any haploid plant, is a potential DH line, such losses need to be minimized.

Table 3. Frequency of properties in eleven Do haploid populations.

Tablica 3. Frekvencija svojstava u jedanaest DO populacija haploida.

\begin{tabular}{|c|c|c|c|c|c|c|}
\hline $\begin{array}{l}\text { Population } \\
\text { Populacija }\end{array}$ & $\begin{array}{l}\text { Pedigree } \\
\text { Pedigre }\end{array}$ & $\begin{array}{c}\text { Emergence } \\
\text { (\%) } \\
\text { Nicanje (\%) }\end{array}$ & $\begin{array}{c}\text { Misclassification (\%) } \\
\text { Pogrešna } \\
\text { klasifikacija (\%) }\end{array}$ & $\begin{array}{c}\text { Colchicine } \\
\text { treatment survival (\%) } \\
\text { Preživljavanje } \\
\text { tretmana kolhicinom } \\
\text { (\%) }\end{array}$ & $\begin{array}{l}\text { Chromosome } \\
\text { doubling (\%) } \\
\text { Udvostručenje } \\
\text { kromosoma (\%) }\end{array}$ & $\begin{array}{c}\text { Self-pollination } \\
\text { success (\%) } \\
\text { Uspješnost } \\
\text { samooplodnje (\%) }\end{array}$ \\
\hline Os 2701 & OS 298P & 46.1 & 1.1 & 96.6 & 26.1 & 40.9 \\
\hline Os 2702 & OS 378 & 47.6 & 1.5 & 93.6 & 21.8 & 61.2 \\
\hline Os 2703 & DRAVA 404 & 57.6 & 1.4 & 89.2 & 20.5 & 69.2 \\
\hline Os 2704 & OS 430 & 37.8 & 3.4 & 94.6 & 13.1 & 62.5 \\
\hline Os 2705 & OSSK 444 & 44.3 & 0.8 & 97.1 & 21.0 & 62.0 \\
\hline Os 2706 & OSSK 515 & 65.6 & 1.7 & 94.5 & 9.9 & 43.2 \\
\hline Os 2707 & OS 499 & 56.7 & 1.4 & 81.1 & 8.1 & 50.0 \\
\hline Os 2708 & OSSK 552 & 26.4 & 0.0 & 50.5 & 11.8 & 50.0 \\
\hline Os 2709 & OSSK 5717 & 53.0 & 2.0 & 94.7 & 31.1 & 56.0 \\
\hline Os 2710 & OSSK 596 & 40.3 & 4.9 & 87.2 & 12.5 & 64.7 \\
\hline Os 2711 & OSSK 617 & 48.1 & 19.8 & 63.5 & 26.4 & 67.6 \\
\hline \multicolumn{2}{|c|}{ Average/Prosjek } & 47.6 & 3.5 & 85.7 & 18.4 & 57.0 \\
\hline \multicolumn{2}{|l|}{$x^{2}$} & $* *$ & $* *$ & $* *$ & $* *$ & n.s. \\
\hline
\end{tabular}

The misclassification rates of a haploid seed can become a significant problem if the rates are too high and a general guide is that the misclassification rates should be kept below $10 \%$ at their very best (De La Fuente et al., 2018). For the specific populations included in the study, only 0s 2711 manifested an unacceptable misclassification rate (Table 3). On average, the misclassification rates were lower than those reported by other authors, usually ranging form $0-45 \%$ (Kebede et al., 2011; Prigge et al., 2011; De La Fuente et al., 2018).

The best recovery subsequent to a colchicine treatment was demonstrated by the haploid plants in the population of 0 s 2705 , while in the 0 s 2708 population only a half of the haploid plants survived a chromosome doubling treatment. On average, a colchicine treatment survival was $85.7 \%$ for all populations (Table 3). Lower seedling survival rates were observed in other studies, commonly amounting to $60-70 \%$ on average (Dang et al., 2012; Battistelli et al., 2013; Jiang et al., 2017).

The chromosome doubling rates ranged from 8.1$31.1 \%$ (Table 3). Zabirova and Shatskaya (1999) reported a success of chromosome doubling amounting to $25-35 \%$ on average, and in some genotypes up to $60 \%$, while other authors achieved significantly lower chromosome doubling rates while using this method in the field conditions. Eder and Chalyk (2002) tested the method in the greenhouse and field conditions. In the greenhouse, $42.4 \%$ of the haploid plants produced fertile pollen and $30.5 \%$ of them could be selfed, whereas $16.1 \%$ of the haploid plants in the field were the male fertile ones, $11.3 \%$ of them could be self-pollinated, and $8.1 \%$ produced seeds after selfing. Vanous et al. (2017) quoted that the doubling rates usually range between $20-25 \%$. Self-pollination in the DO generation was the most successful in the population of 0 s 2703 , in which $69.2 \%$ of fertile plants produced seed (Table 3 ). The results of this study confirmed the earlier findings by Dang et al. (2012), according to which the colchicine treated haploid plants, though fertile, are usually weak and have a long anthesis silking interval (ASI), which is a main bottleneck when opting to perform the selfing successfully. Furthermore, colchicine is light- and temperature-sensitive, so it is important to maintain the temperature under $25^{\circ} \mathrm{C}$ during the colchicine treatment because the higher temperatures may decrease the doubling rates (Barow, 2006).

Finally, the DH deriving rates ranged from 0.8 to $7.8 \%$, expressed as a percentage of the putative haploid 
seeds that resulted in a DH line (Table 4). Vanous et al. (2017) noted that the success rates usually range from 8 to $10 \%$. Taking into account that a large number of putative haploids were lost due to the low emergence rates, we also calculated the deriving rates based on a total number of DO haploids, resulting in $2.2-15.0 \%$ of
DH lines per population (Table 4). These results suggest that the low emergence rates had a great impact on the efficiency of the method in total, confirming that the haploids should be sown in the conditions that enable undisturbed emergence.

Table 4. Doubled haploids deriving rates.

Tablica 4. Stope dobivanja udvostručenih haploida.

\begin{tabular}{|c|c|c|c|}
\hline \multirow{2}{*}{$\begin{array}{l}\text { Population } \\
\text { Populacija }\end{array}$} & \multirow{2}{*}{$\begin{array}{c}\text { Number of DH lines } \\
\text { Broj DH linija }\end{array}$} & \multicolumn{2}{|c|}{$\begin{array}{l}\text { DH deriving rates (\%) } \\
\text { Stope dobivanja } \mathrm{DH}(\%)\end{array}$} \\
\hline & & Rate 1 & Rate 2 \\
\hline Os 2701 & 30 & 3.9 & 8.6 \\
\hline Os 2702 & 36 & 5.1 & 11.0 \\
\hline Os 2703 & 81 & 6.5 & 11.4 \\
\hline Os 2704 & 16 & 2.3 & 6.2 \\
\hline Os 2705 & 24 & 4.3 & 9.8 \\
\hline Os 2706 & 14 & 1.9 & 3.0 \\
\hline 0s 2707 & 6 & 1.2 & 2.2 \\
\hline Os 2708 & 3 & 0.8 & 3.0 \\
\hline 0s 2709 & 51 & 7.8 & 15.0 \\
\hline Os 2710 & 9 & 2.2 & 5.8 \\
\hline Os 2711 & 18 & 3.4 & 8.9 \\
\hline
\end{tabular}

Rate 1 - DH deriving rate based on the total number of putative haploid seeds / stopa dobivanja DH na osnovi ukupnog broja navodno haploidnih zrna; Rate 2 - DH deriving rate based on the total number of DO haploids / stopa dobivanja DH na osnovi ukupnog broja DO haploida.

In order to achieve the higher emergence rates and better selfing results, the haploids of the D0 generation should be sown in a protected area, such as a greenhouse, and then transplanted to the field subsequent to a colchicine treatment. Such an application would facilitate a better and a more equal emergence, thus enabling a colchicine solution application in the optimal growth stage for all the haploid plants, and reduce the stress effects caused by the treatment and a partial condition control during and immediately after the colchicine treatment.

\section{CONCLUSION}

The haploid induction rates were consistent with the average induction rates characteristic of the ZMK inducer and other modern inducers, indicating that the examined hybrids were a suitable source material for an in vivo induction. Significant differences were found between the populations of $\mathrm{DO}$ haploids for all the tested properties, except for a self-pollination success. On average, the misclassification rates were lower whereas the seedling survival rates were higher than those reported in other studies. We can conclude that an in vivo haploid induction using the ZMK inducer has a great potential for maize breeding. However, a management of the DO haploids should be improved to increase efficiency in the DH lines development.

\section{ACKNOWLEDGEMENT}

This study was supported by the EU project KK.01.1.1.01.0005 Biodiversity and Molecular Plant Breeding of the Centre of Excellence for Biodiversity and Molecular Plant Breeding (CroP-BioDiv), Zagreb, Croatia.

\section{REFERENCES}

1. Barow, M. (2006). Endopolyploidy in seed plants. BioEssays 28(3), 271-281. https://doi.org/10.1002/ bies.20371

2. Battistelli, G. M., Von Pinho, R. G., Justus, A., Couto, E. G. O., \& Balestre, M. (2013). Production and identification of doubled haploids in tropical maize. Genetics and Molecular Research 12(4), 4230-4242. https://doi.org/10.4238/2013.0ctober.7.9

3. Bernardo, R. (2009). Should maize doubled haploids be induced among F1 or F2 plants? Theoretical and Applied Genetics 119(2), 255-262.

https://doi.org/10.1007/s00122-009-1034-1

4. Chalyk, S. T. (1999). Use of maternal haploids for improving maize inbred lines. Maize Genetics Cooperation Newsletter 73, 54-56.

5. Dang, N. C., Munsch, M., Aulinger, I., Renlai, W., \& Stamp, P. (2012). Inducer line generated double haploid seeds for combined waxy and opaque 2 grain qulity in subtropical maize (Zea mays L.). Euphytica 183(2), 153-160. https://doi.org/10.1007/s10681-011-0423-0 
6. De La Fuente, G. N. (2015). Improvements to the maize (Zea mays L.) in vivo maternal doubled haploid system. Graduate Theses and Dissertations 14767. lowa State University, Ames, lowa. Retrieved from https://lib.dr.iastate.edu/etd/14767

7. De La Fuente, G. N., Frei, U. K., Trampe, B., Nettleton, D., Zhang, W., \& Lübberstedt, T. (2018). A diallel analysis of a maize donor population response to in vivo maternal haploid induction I: Inducibility. Agronomy Publications 507. lowa State University, Ames, lowa. Retrieved from https://lib.dr.iastate.edu/agron_pubs/507 https://doi.org/10.2135/cropsci2017.05.0285

8. Eder, J., \& Chalyk, S. (2002). In vivo haploid induction in maize. Theoretical and Applied Genetics 104(4), 703-708. https://doi.org/10.1007/s00122-001-0773-4

9. Galić, V., Franić, M., Jambrović, A., Zdunić, Z., Brkić, A., \& Šimić, D. (2017). OTL mapping for grain quality traits in testcrosses of a maize biparental population using genotyping-by-sequencing dana. Poljoprivreda,23(1), 28-33. https://doi.org/10.18047/poljo.23.1.5

10. Geiger, H. H. (2009). Doubled haploids. In J. L. Bennetzen, \& S. Hake (Eds.), Maize Handbook. Vol 2: Genetics and Genomics (pp. 641-659). Springer Verlag, Heidelberg, New York.

11. Hallauer, A. R., Carena, M. J., \& Miranda Filho, J. B. (2010). Quantitative genetics in maize breeding. Quantitative genetics in maize breeding (Vol. 6). Springer Science \& Business Media.

12. Jiang, L., Yang, X. Y., Li, X. Y., Deng, P. K., Jing, G. X., Wang, X. 0., ... \& Zhao, R. G. (2017). A study on natural recovery of tassel fertilization and doubling method in maize haploids. Genetics and Molecular Research 16 (1), gmr16019173.

https://doi.org/10.4238/gmr16019173

13. Jug, D., Jug, I., Brozović, B., Vukadinović, V., Stipešević, B., \& Đurđević, B. (2018). The role of conservation agriculture in mitigation and adaptation to climate change. Poljoprivreda, 24(1), 35-44. https://doi.org/10.18047/poljo.24.1.5

14. Kebede, A. Z., Dhillon, B. S., Schipprack, W., Araus, J. L., Bänziger, M., Semagn, K., Alvarado, K., \& Melchinger, A. E. (2011). Effect of source germplasm and season on the in vivo haploid induction rate in tropical maize. Euphytica 180 (2), 219-226. https://doi.org/10.1007/s10681-011-0376-3

15. Lashmermes, P., \& Beckert, M. (1988). Genetic control of maternal haploidy in maize (Zea mays L.) and selection of haploid inducing lines. Theoretical and Applied Genetics 76(3), 405-410. https://doi.org/10.1007/BF00265341

16. Nanda, D. K., \& Chase, S. S. (1966). An embryo marker for detecting monoploids of maize (Zea mays L.). Crop Science 6(2), 213-215. https://doi.org/10.2135/cropsci1966.0011183X000600020036x
17. Prigge, V., Sánchez, C., Dhillon, B. S., Schipprack, W., Araus, J. L., Bänziger, M., \& Melchinger, A. E. (2011). Doubled haploids in tropical maize: I. Effects of inducers and source germplasm on in vivo haploid induction rates. Crop Science 51(4), 1498-1506. https://doi.org/10.2135/cropsci2010.10.0568

18. Röber, F. K., Gordillo, G. A., \& Geiger, H. H. (2005). In vivo haploid induction in maize - Performance of new inducers and significance of doubled haploid lines in hybrid breeding. Maydica 50(3-4), 275-283.

19. Rotarenco, V., Dicu, G., State, D., \& Fuia, S. (2010). New inducers of meternal haploids in maize. Maize Genetics Cooperation Newsletter 84, 1-7.

20. Sarkar, K. R., Pandey, A., Gayen, P., Mandan, J. K., Kumar, R., \& Sachan, J. K. S. (1994). Stabilization of high haploid inducer lines. Maize Genetics Cooperation Newsletter 68, 64-65.

21. Shatskaya, 0. A. (2010). Haploinductors isolation in maize: three cycles of selection on high frequency of induction of matroclinal haploids. Agricultural Biology 5, 79-86.

22. Shatskaya, 0. A., Zabirova, E. R., Shcherbak, V. S., \& Chumak, M. V. (1994). Mass induction of maternal haploids in corn. Maize Genetics Cooperation Newsletter 68, 51. http://www.agrobiology.ru/articles/5-2010shatskaya-eng.pdf

23. Smith, J. S. C., Hussain, T., Jones, E. S., Graham, G. Podlich, D., Wall, S., \& Williams, M. (2008). Use of doubled haploids in maize breeding: implications for intellectual property protection and genetic diversity in hybrid crops. Molecular Breeding 22(1), 51-59. https://doi.org/10.1007/s11032-007-9155-1

24. Vanous, K., Vanous, A., Frei, U. K., \& Lübberstedt, T. (2017). Generation of maize (Zea mays) doubled haploids via traditional methods. Current Protocols in Plant Biology 2(2), 147-157. https://doi.org/10.1002/cppb.20050

25. Wilde, K., Burger, H., Prigge, V., Presterl, T., Schmidt, W., Ouzunova, M., \& Geiger, H. H. (2010). Testcross performance of doubled-haploid lines developed from European flint maize landraces. Plant Breeding 129(2), 181-185.

https://doi.org/10.1111/j.1439-0523.2009.01677.x

26. Zabirova, E. R., \& Shatskaya, O. A. (1999). Effektivnost metoda gaploidii pri sozdanii elitnih linij kukuruzi. In Genetika, selekcija i tehnologija vozdelivanija kukuruzi. Krasnodar (in russian)

27. Zhang, Z., Qiu, F., Liu, Y., Ma, K., Li, Z., \& Xu, S. (2008). Chromosome elimination and in vivo haploid production induced by Stock 6-derived inducer line in maize (Zea mays L.). Plant Cell Reports 27(12), 1851-1860. https:// doi.org/10.1007/s00299-008-0601-2 


\section{RAZVOJ HOMOZIGOTNIH LINIJA KUKURUZA POMOĆU INDUKCIJE HAPLOIDA IN VIVO U HRVATSKOJ GERMPLAZMI}

\section{SAŽETAK}

Indukcija haploida in vivo posljednjih se desetljeća sve više primjenjuje u oplemenjivanju kukuruza, ali se dosad nije koristila u oplemenjivačkim programima u Republici Hrvatskoj. Ciljevi ovoga istraživanja bili su utvrditi relativne frekvencije induciranih haploida kod germplazme koja se upotrebljava u domaćim oplemenjivačkim programima $i$ ispitati svojstva haploida generacije DO koja su važna za uspješnu primjenu ove metode u oplemenjivanju. Indukcija haploida in vivo obavljena je na 11 jednostrukih hibrida pomoću induktora ZMK, a za udvostručenje kromosoma korišten je kolhicin. U generaciji DO ispitana su svojstva nicanja, pogrešne klasifikacije, preživljavanja tretmana kolhicinom, udvostručenja kromosoma $i$ uspješnosti izvođenja samooplodnje. Relativna frekvencija haploida kretala se od 6,9 do 15,8\%, što je usporedivo $s$ prosječnim stopama indukcije specifičnim za induktor ZMK i druge moderne induktore. Statistički značajne razlike pronađene su između populacija haploida DO za sva ispitana svojstva, osim za uspješnost izvođenja samooplodnje. U prosjeku, stope pogrešne klasifikacije bile su niže, a stope preživljavanja tretmana kolhicinom više u odnosu na one zabilježene u drugim istraživanjima, što ukazuje na mogućnost uspješne primjene metode udvostručenih haploida u oplemenjivanju.

Ključne riječi: indukcija haploida in vivo, udvostručene haploidne linije, sustav markera R-nj , udvostručenje kromosoma, kolhicin

(Received on November 12, 2018; accepted on March 2, 2019 - Primljeno 12. studenoga 2018.; prihvaćeno 21. ožujka 2019.) 